\title{
Directions for future management of North Island Weka Gallirallus australis greyi to improve survival and productivity in situ
}

\author{
GARY N. BRAMLEY and CLARE J. VELTMAN
}

\begin{abstract}
Summary
We investigated how North Island Weka Gallirallus australis greyi could be conserved in situ at East Cape, New Zealand using banded and radiotransmitter-carrying Weka to measure home range size and use, reproduction and mortality. We fitted radiotransmitters to 28 Weka with $75 \%$ of the subsequent fixes from 18 birds being obtained at intervals of $<4$ days. Home ranges of 10 males had an estimated median size of 10.6 ha, while 5 female home ranges had an estimated median size of 3.5 ha. Home ranges of individuals of both sexes overlapped. Within their home ranges, Weka preferred bush relative to pasture and may have preferred pines to pasture. Weka did not significantly prefer bush to pines. Breeding occurred year-round, with a summer peak, but 11 breeding pairs raised only four chicks to independence in two years. The causes of egg and chick mortality could not be established, but predators killed six adults, motor vehicles killed six and one adult died in a trap. Measurements of body size revealed that a male-biased sex ratio was likely (67:33). We concluded that the recovery of the North Island Weka population in the East Cape region will require improving reproductive success and decreasing predation on adults. We recommend that managers focus on predator removal and habitat creation in future.
\end{abstract}

\section{Introduction}

The North Island Weka Gallirallus australis greyi is a flightless New Zealand rail that was formerly widespread (Marchant and Higgins 1993, Beauchamp 1997, Beauchamp et al. 1998), but is now found only at East Cape and on three islands (Figure 1). North Island Weka are classified as endangered (IUCN 1994).

We envision four strategic approaches for conserving North Island Weka. First birds might be liberated to establish new populations on offshore islands free of the predatory mammals that have extirpated other New Zealand birds (Innes and Hay 1991, McLennan et al. 1996). Unfortunately Weka include birds eggs, reptiles and invertebrates in their diet (Carroll 1963a, Bramley 1994) and the introduction of Weka to island sanctuaries could in turn threaten other endangered endemic wildlife (St Clair and St Clair 1992). As a result, this is a strategic option that is not favoured by conservation managers (Beauchamp et al. 1999). Despite this, Weka have been introduced to two offshore islands in the past three years (Whanganui Island and Pakatoa Island in the Hauraki Gulf; Graeme 1997). Pakatoa Island is a small (24 ha), highly modified holiday resort, and Whanganui Island is within swimming distance of stoats Mustela erminea from Coromandel Peninsula, so both islands are of limited conservation value for other endemic species.

A second strategy for Weka conservation is to establish new populations on North Island using birds captured in the wild or birds bred in captivity for the 


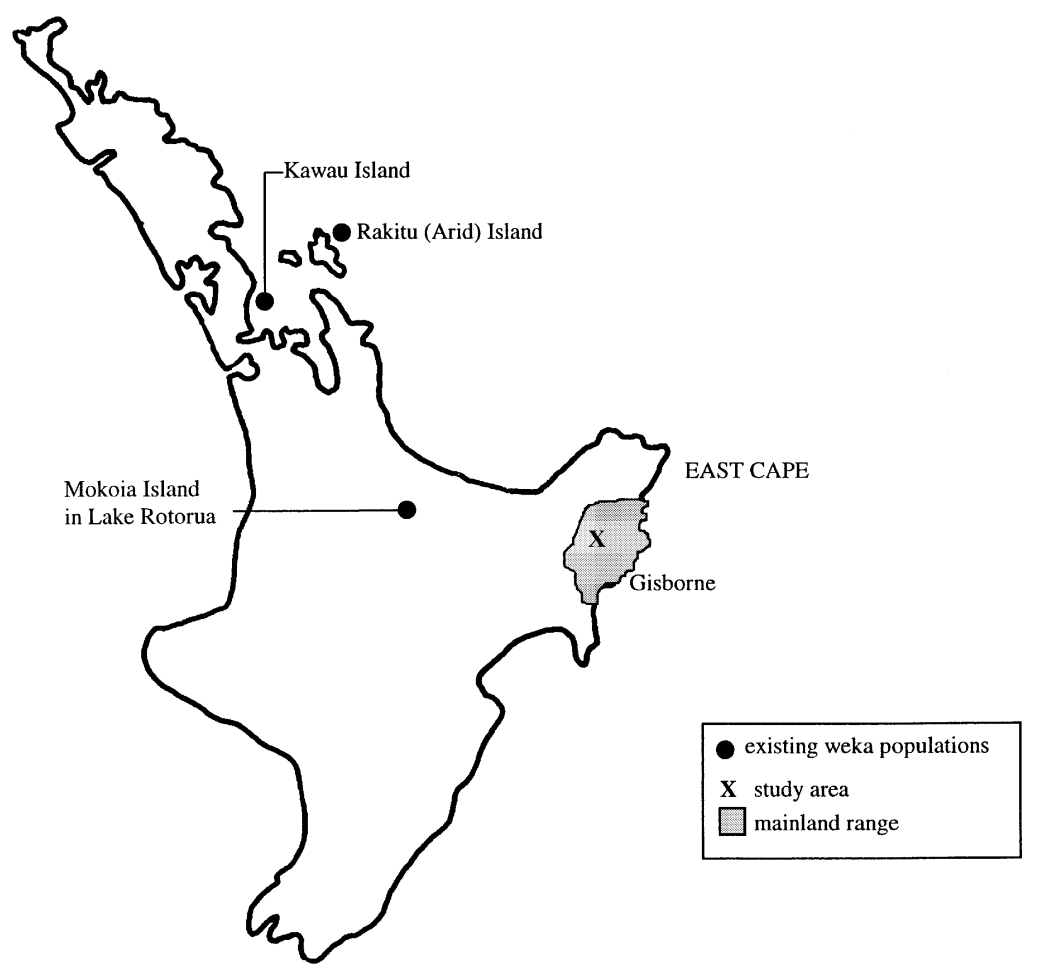

Figure 1. Location of extant populations of North Island Weka, New Zealand.

purpose. Previous attempts to establish new North Island populations, including those using captive-bred birds, have failed (Bramley and Veltman 1998). Until more is known about habitat use by Weka and the agents of decline at mainland sites it is unlikely that such liberations will be accompanied by appropriate actions to lessen Weka mortality in the area to be colonized.

A third strategy is to establish new Weka populations in "mainland islands" (Saunders 1990: forested reserves in which there is intensive control of herbivorous and predatory mammalian pests). Thus Weka could help re-form a preEuropean natural community in a protected environment and become source populations (Harrison 1991) for emigration into surrounding patches. However, it will be difficult to present toxins to pests in a way that does not expose Weka, which are omnivores, and the concern that Weka will endanger other native wildlife still remains.

A fourth strategy is to manage the remaining East Cape population in situ, manipulating either the birds or their habitat, or both, to increase numbers to a viable population size (Brook et al. 1997). To do so, managers require information about habitat use, reproduction and survival of North Island Weka at East Cape.

We used radio-telemetry to study home ranges, breeding and causes of mortality of Weka at Rakauroa, a farming district approximately $62 \mathrm{~km}$ west of Gisborne (Figure 1). As we report here, our results not only point to management actions for conservation of the existing population, but also will help in site pre- 
parations for any future efforts to establish new Weka populations on North Island.

\section{Methods}

Study area

Rakauroa $\left(38^{\circ} 25^{\prime} \mathrm{S}\right.$ and $\left.177^{\circ} 34^{\prime} \mathrm{E}\right)$ is a valley situated $7.5 \mathrm{~km}$ east of Matawai on State Highway Two, North Island, New Zealand (Figure 1). The valley is bisected by the Waikohu River and varies in elevation from $200 \mathrm{~m}$ to $900 \mathrm{~m}$ asl. Rakauroa has reliable summer rainfall (five year average 1988-1992, 1,429 mm/year, National Institute of Water and Atmospheric Research data, Rotorua, New Zealand). The climate is temperate, with hot summers and cool winters. December and February are the driest months and August, September and October the wettest. The region is extensively farmed for meat and wool products and is mostly grassland with patches of riparian vegetation and areas, especially in the gullies, of regenerating scrubland (dominated by Manuka Leptospermum scoparium, Coprosma species, Fivefinger Pseudopanax arborea and ferns). The riparian vegetation and roadside scrublands form corridors of cover in the grassland. There were five small native forest patches and several small exotic pine Pinus radiata plantations of varying age in the area.

We commenced our study in March 1992 and completed fieldwork in January 1994. One or both of us made trips to the area monthly, except in October 1992, and we spent 223 days in the area (4-22 days per month). We estimated the size of the study area from aerial photographs, taking no account of the slope of the land. To determine the edge of the study area we plotted the location of all birds seen or heard calling (Bramley and Veltman, in press) on to a map drawn from the aerial photographs and drew around it. In areas that had been investigated but where no birds were detected, we assigned the boundary according to local topography, which determined the distance over which birds could be heard (i.e. detected).

\section{Capture, measurement and banding}

Weka were caught using wire cage traps measuring $300 \times 300 \times 700 \mathrm{~mm}$ long, and baited with cheese on a hook suspended near the back of the trap. Traps were positioned along corridors of dense vegetation or in places near where Weka had been seen. Morphometric measurements were taken to determine the sex of Weka (Carroll 1963b). The departure of the sex ratio of captured birds from 1:1 was tested using the Chi-square procedure. The time until capture for adult males and adult females was compared using a $t$-test on log-transformed data to determine if birds of one sex were more quickly trapped. Only adult birds were used because we considered that the sexes of adult birds were more reliably determined.

From August 1992 until January 1994 all captured adults were banded with an individual combination of two coloured plastic bands and one numbered metal band (New Zealand Banding Service). Captured juveniles were given one metal band and either one or two coloured plastic bands in unique combinations. 
We aged Weka by their plumage and the colour of their eyes, which changes from liver brown to red at approximately five months of age (Beauchamp 1998). Adult plumage is attained at approximately 70-90 days (Beauchamp 1998). Birds with red irides and adult plumage were classified as adults, those with brown irides and adult plumage were classified as juveniles. Birds with immature plumage were called chicks.

\section{Radio-telemetry}

Back-mounted, two-stage VHF transmitters set at 40 pulses/min and weighing an average of $19.3 \mathrm{~g}$ were fitted to 28 birds. The radios were equipped with a 10-month battery cell and had external whip-type aerials (Sirtrack Telemetry Electronics, Havelock North, New Zealand). Radios were attached by nylon loops to the bird's back, between the wings, much as a human might wear a backpack. A "weak link" of cotton in the nylon loops meant that birds could free themselves if snagged (as occurred in at least five cases).

Signals from the radiotransmitters were tracked using a MERL receiver (CE12, Custom Electronics of Urbana, Urbana, IL) until November 1992. From November 1992, a TR-4 receiver was used (Telonics Telemetry Electronics Consultants, Mesa, AZ). Both receivers were combined with a hand-held, three-element Yagi antenna.

We chose Weka at random by drawing band combinations out of a hat with replacement to check locations at randomly chosen times of the day, determined by drawing hourly times from a hat without replacement. Weka were initially followed for $1 \mathrm{~h}$ at a time. By November 1992 it became clear that birds were rarely visible and seldom moved in an hour of observation, so birds were then followed for up to $7 \mathrm{~h}$ /day from November 1992 to January 1993. This did not produce the expected increase in observability, so we returned to following the animals for 1 h. From October 1993, because of other fieldwork, bird positions were checked more often (daily), but we did not follow birds at all. This resulted in a lower ratio of Weka observations per hour in the field. We gathered point locations for up to 312 days (range 13-312) from individuals.

We located animals by triangulation from a distance of $<20 \mathrm{~m}$. Once we were confident of a Weka's position, we moved as far as possible from the bird while still being able to see its location. We were able to correctly locate removed radios and dead Weka with attached radios, which provided a check on our accuracy of point location estimation. We also hunted for three hidden radios at the beginning of the study to check our accuracy. Our error in estimating point locations

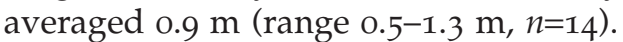

Only the point at which an animal was first found was used as an independent point location. If a bird was found more than once on a given day, but had not been followed between locations, then both observations were treated as independent (they were always separated by at least $2 \mathrm{~h}$ ). All Weka were checked at least twice during each monthly visit to ensure they were still alive and carrying a radio.

The point locations were marked on 1:10,000 aerial photographs of the area (Department of Survey and Land Information, Gisborne). Home range sizes were then estimated using the minimum convex polygon method (Hough 1982). The 
polygons were drawn on paper, cut out, weighed and converted to area measurements. The computer package Ranges V (Institute of Terrestrial Ecology, Furzebrook Research Station, Wareham, Dorset, U.K.) was used to calculate the incremental area of the home ranges and determine how many fixes were necessary to determine each home range reliably.

The home range sizes of male, female and juvenile Weka were compared with each other using a Wilcoxon-Mann-Whitney test. Because this test assumes independence between individuals, in cases where both members of a mated pair carried radios, only the female was included, to increase the sample size for females. The distance moved between consecutive fixes for adult Weka (either within the same field visit or between two visits) was measured from the aerial photographs. These data were averaged for each Weka. Movement within a field visit was then compared with movement between field visits using a Wilcoxon signed ranks test.

We attempted to establish the breeding status of each bird by hunting for nests in areas where radio-carrying birds were repeatedly found. When it was established that Weka were breeding, we were able to check the nest and record the outcome. It was also possible to observe non-radio-carrying adult pairs that had successfully hatched chicks because pairs with chicks were highly visible while they were feeding young.

Radiotransmitters were recovered either by retrapping individuals, finding transmitters that had been removed, or by finding dead birds to which radios were still attached.

\section{Habitat use and Weka behaviour}

Vegetation in each home range was grouped into one of eight classes: pine forest, ungrazed native forest, ungrazed scrubland with regeneration, grazed native forest and scrubland with little regeneration, grazed pasture, ungrazed pasture, woodpiles (cut or fallen logs overgrown by weeds and climbers), and "unusable" areas such as roads, houses and the river. Using aerial photographs and estimates obtained by walking over the area, we measured the availability of each of these vegetation classes in each animal's home range by cutting out scaled maps and weighing the relevant pieces. The weights were then converted to area measurements. When radio-carrying Weka were located, the type of habitat they were in was recorded. Availability of vegetation classes and their use by Weka within their home ranges was compared using compositional analysis (log-ratio differences, Aebischer and Robertson 1992, Aebischer et al. 1993). Because not all birds included all habitat types in their home ranges, habitat types were lumped into three groups based on the level of cover they provided to minimize missing values. Pasture provided no cover, and ungrazed pasture provided little cover and hindered Weka movement, so these two categories were combined into one type and called "pasture". Forest, ungrazed scrubland and woodpiles all had abundant low, dense cover and were combined and called "bush". Pines and ungrazed scrubland had little low cover available and were combined and called "pines". This meant the data from 14 birds could be used in the compositional analysis. We also calculated Manly's standardized selection index (using the 
formula $B_{i}=$ (no. locations recorded in habitat/no. locations expected in habitat) $/ \Sigma$ (no. locations recorded in habitat/no. locations expected in habitat); Manly et al. 1993) to determine the relative preference of Weka for each habitat type.

When Weka were visible, we recorded behaviour using a continuous alloccurrence sampling rule into a hand-held tape recorder. Weka behaviour was scored in seven categories: feeding, walking or running, standing or sitting, preening, parental care, vocalizing and distraction displays. When we observed family groups, we recorded only the behaviour of the bird thought to be the male, because males were considered more likely to be visible, hence a larger data set could be accumulated. Weka were followed until they had not been seen for 10 mins, or in the case of radio-carrying birds, until the observation hour had elapsed.

\section{Results}

We banded 35 adult Weka between August 1992 and January 1994. From culmen and tarsal measurements and bodyweights (Carroll 1963b) we sexed them as $24(68.6 \%)$ males and 11 females. We also captured 24 young Weka including seven chicks. We were able to sex the 17 juveniles as $11(64.7 \%)$ males and six females. Overall, the population's sex ratio was significantly male-biased in our samples $\left(\chi^{2}=6.23, d f=1, P<0.05\right)$. There was no significant difference in trapability, based on time taken to catch an adult of each sex for the first time (males: mean 9.5 trap nights, females: 14.4 trap nights, two-sample $t$-test on log-transformed data, $P=0.23$ ). However we cannot rule out that males were more likely to be trapped because the small sample size will reduce the statistical power of the $t$-test. We observed an additional nine unbanded adults in the study area and estimated the maximum density of adults to be 0.4 Weka per hectare (44 birds from 105 ha).

\section{Home range sizes}

We obtained home range data from 18 Weka (10 males, 4 females, 1 juvenile female and 3 juvenile males). The mean number of fixes was $27.1 \quad(n=18, \mathrm{SD}=$ 17.02) per Weka. The mean time between radio fixes for all birds, within and between trip data combined, was 5.74 days ( $\mathrm{SD}=9.8$ days). Most $(75.86 \%$ consecutive fixes were less than $200 \mathrm{~m}$ apart (Figure 2), and the largest recorded movement between fixes was $940 \mathrm{~m}$. Ninety per cent of an individual's home range size could be estimated with a standard deviation of $5 \%$ using 26 fixes. Male home range areas (median 10.56 ha, $n=10$ ) were significantly larger than home ranges used by females (median 3.5 ha, $n=5$, MannWhitney $U=80.0, P<0.05$ ) and juveniles (median 1.25 ha, $n=3$, Mann-Whitney $U=79.5, P<0.05)$.

Movements by Weka either within or between trips were not significantly different (males: $Z=0.978, P=0.328, n=11$; females: $Z=1.461, P=0.144, n=3$ ).

Home ranges of adults overlapped. Adjacent resident Weka made use of the same patches of cover or bush within their home ranges. On one occasion 


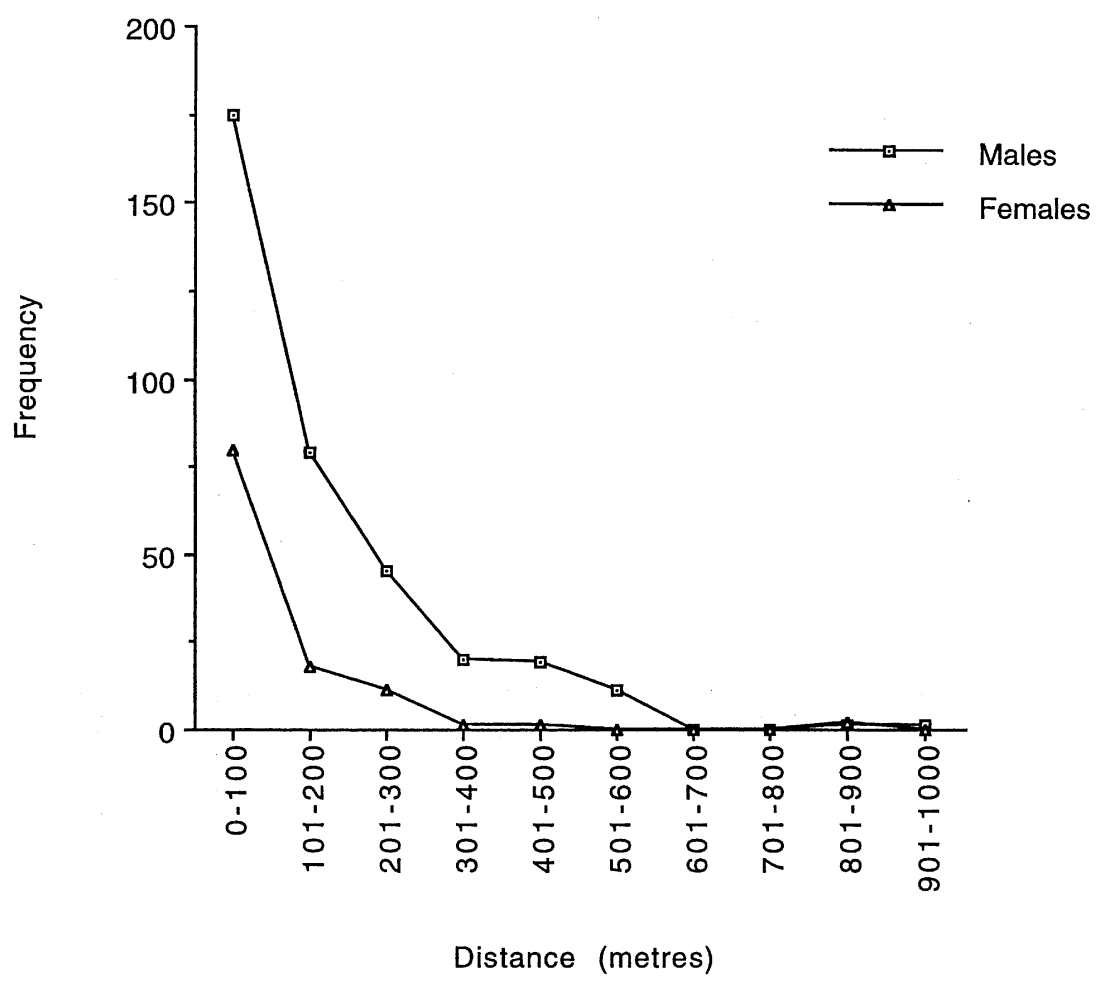

Figure 2. Movements made by radio-carrying Weka between fixes at Rakauroa, North Island, New Zealand.

we saw two individuals foraging $<50 \mathrm{~m}$ from each other, and we never observed behaviour consistent with territoriality.

\section{Home range use and Weka behaviour}

Only individuals with $\geqslant 17$ fixes were used to estimate home range area and for compositional analysis. The 14 birds used in the compositional analysis had a mean of 30.3 fixes $(S D=17.64)$. Each home range was made up of a mosaic of different vegetation types. Some Weka also used small underground caverns ("underrunners"; Carroll 1963c), but we could not measure the availability of these to the birds. Two individuals were each located twice in underrunners.

Weka used ungrazed scrubland and woodpiles much more than expected from their availability. After grouping the cover type data, the compositional analysis of the home range of the 14 Weka with all three habitat types showed that "bush" was the preferred habitat type relative to "pasture" (mean log ratio difference 5.53, $\mathrm{SE}=1.22, n=14)$ and "pines" (mean $\log$ ratio difference 2.70, $\mathrm{SE}=0.82, n=14$ ). "Pines" were also preferred over "pasture" (mean log ratio difference 2.84, SE= 1.28). Two sample $t$-tests showed that "bush" was significantly preferred over "pasture" ( $t=3.63, P=0.0015)$. There was no significant difference between "pines" 
Table 1. Relative probabilities of habitat selection by Weka at Rakauroa, North Island, New Zealand. Eight different habitat types were identified and then grouped according to the level of cover they provided (see text)

\begin{tabular}{lcllll}
\hline Habitat & $\begin{array}{l}\text { Number of } \\
\text { fixes } \\
\text { recorded }\end{array}$ & $\begin{array}{l}\text { Expected } \\
\text { number of } \\
\text { fixes based } \\
\text { on } \\
\text { availability }\end{array}$ & $\begin{array}{l}\text { Expected } \\
\text { proportion } \\
\text { of fixes }\end{array}$ & $\begin{array}{l}\text { Selection ratio } \\
\text { (proportion } \\
\text { recorded/ } \\
\text { proportion } \\
\text { expected) }\end{array}$ & $\begin{array}{l}\text { Standardized } \\
\text { selection } \\
\text { index }\left(\mathrm{B}_{\mathrm{i}}\right)\end{array}$ \\
\hline Pasture & 32 & 267.0289 & 0.6434 & 0.1198 & 0.0165 \\
Bush & 194 & 37.5490 & 0.0905 & 5.1665 & 0.7133 \\
Pines & 189 & 96.5676 & 0.2327 & 1.9571 & 0.2702 \\
Unusable & 0 & 13.8600 & 0.3340 & 0 & 0 \\
Total & 415 & 415 & 1.00 & 7.2434 & 1.00 \\
\hline
\end{tabular}

and "pasture" at the 0.95 level, but there was at the 0.90 level, with "pines" being preferred $(t=1.93, P=0.067)$. There was no significant difference between "bush" and "pines" ( $t=1.53, P=0.14)$. Weka were approximately 2.6 times more likely to select "bush" than "pines" and 43 times more likely to select "bush" than pasture (Table 1). Weka selected "pines" approximately 16 times more often than they selected "pasture". These results differ significantly from random selection $\left(\chi^{2}=755.18, d f=3, P<0.01\right)$, indicating that Weka prefer denser habitats rather than more open ones.

Radio-carrying Weka spent most of their time immobile and under cover. Of 268 encounters with Weka in 1301 hours spent in the field, 52 (19.4\%) were long enough to record behaviours. From 303 hours of observation of radio carrying and other birds, Weka were visible for 489 minutes (2.69\%). The average observation episode lasted 9 minutes and $24 \mathrm{~S}(\mathrm{SD}=12 \min 18 \mathrm{~s})$. Feeding was the most frequently observed behaviour ( $52.7 \%$ of time), followed by standing or sitting $(25 \%)$, walking or running (11.1\%), preening $(6 \%)$, distraction behaviours $(3.4 \%)$, vocalizing (1.5\%) and courtship and parental care (0.4\%).

\section{Reproduction}

We inferred nest initiation from radio tracking or by estimating the age of chicks. Weka nested in all months except February and May, with a peak during summer (November to January). In all, 25 nest attempts were recorded either directly or from the appearance of chicks. Egg laying began in four of them in January, one in each of March, April, July and August, two in each of June and October, three in September and five in each of November and December. The mean number of dependent chicks seen $(<56$ days old) was 1.94 per brood $(n=$ 17 broods that hatched chicks, median $=2$, mode $=1$ ).

Between March 1992 and April 1993 eight known females attempted to breed 12 times. From April 1993 to January 1994, 7 of the 1o known females attempted to breed 13 times - clearly some individuals bred more than once in a year. We found five nests, each with four eggs. Three of these nests failed to produce young; the remaining nests resulted in four chicks and one chick respectively. We also became aware of five more nests from monitoring the behaviour of the adults, but could not observe them directly. One of these nests reared one chick and the others were unsuccessful. 
Table 2. Nest occupancy by Weka at Rakauroa, North Island, New Zealand. The number in parentheses is the number of days the nest was followed. The 1992 nest attempt (of four eggs) failed when two eggs were taken by predators and the pair abandoned the nest. Both nest attempts in 1993 were being protected from ferrets and cats (Bramley 1996)

\begin{tabular}{lllllll}
\hline & Female & Male & Neither & Both & $\begin{array}{l}\text { Number of } \\
\text { visits }\end{array}$ & $\begin{array}{l}\text { Chicks } \\
\text { hatched }\end{array}$ \\
\hline Pair 1, 1992 & $39 \%$ & $39 \%$ & $22 \%$ & 0 & $18(18)$ & 0 \\
Pair 1, 1993 & $69 \%$ & 0 & 0 & $31 \%$ & $13(24)$ & 4 \\
Pair 2, 1993 & $43 \%$ & 0 & $14 \%$ & $43 \%$ & $7(7)$ & 1 \\
\hline
\end{tabular}

We were able to watch Weka closely during three breeding attempts. Two were by the same pair (one in 1992 and one in 1993) and one in 1993 was by another pair. Both members of each pair performed incubation and they were often found at the nest together (Table 2).

From March 1992 until March 1993 10 known pairs produced 18 chicks. Only one of those was known to be alive at independence (o.1 chicks/pair per year). Between April 1993 and January 199411 known pairs produced 16 chicks. Three of these survived to independence. Three more chicks were $<9$ weeks old and still alive when the study ended (Bramley 1996). This yields a productivity estimate of 0.6 chicks/pair per 10 months. Nests that failed at an early stage were unlikely to be found; hence our estimates are probably higher than the real proportion of successful nesting attempts by Weka at Rakauroa.

From nests where the number of hatchlings was known, and assuming that broods first seen as chicks had hatched only the chicks observed, survival rate of chicks (number of surviving chicks/number of chicks hatched) to nine weeks old (when they were usually independent) was o.118. The breeding pairs in the valley raised only four chicks to independence in two years.

\section{Recruitment}

Two Weka banded as older juveniles in 1992 were alive in 1993. One, a radiocarrying female, was recruited into the breeding pool six months later and nested $520 \mathrm{~m}$ from her natal area. The other, a male, was still alive six months after banding and had moved 1,500 $\mathrm{m}$ from where he was first caught in the home range of his parents. The one chick that survived to independence in 1992 had entered the breeding population by 21 January 1995 when he was observed breeding with an unbanded female during a call count survey (Bramley and Veltman in press). This bird was occupying an area previously inhabited by his parents, which were both banded. He had not been seen since 15 May 1993 prior to this and it is possible his slow recruitment was due to a shortage of females. The cryptic behaviour of independent, non-breeding young Weka made it difficult to estimate survival accurately.

\section{Mortality}

Freshly dead birds $(n=11)$ were discovered throughout the year: one in each of January, February, March, August and September. Four dead birds were discovered in June and two in December. Only three of these 11 birds were carrying 
radios. The corpses of two freshly killed adults, one of which was carrying a radio, and the bones of three others were found in a large underground cavern in June 1992. The partially decomposed body of another radio-carrying adult male was found in a smaller cavern beside the Waikohu river in June 1993. One of the bite marks in a bone neatly fitted the canine tooth of a ferret Mustela furo. Ferrets are known to be free-living in the area (Bramley 1996). The remaining radio-carrying bird presumably drowned in August 1992. Of the 11 recently dead Weka discovered, measurements (verified by dissection) showed that seven were males and four were females. Of the 14 deaths recorded (11 recent deaths and three skeletons), six were caused by motor vehicles, six were due to predation and one may have drowned. The remaining Weka died in a trap in December 1993.

\section{Discussion}

The birds we studied commenced breeding in their first year, laid eggs yearround, consistently laid four eggs, and made more than one breeding attempt per year. This life history potentially enables rapid colonization of suitable patches, but the density we estimated is at the low end of the range reported for Weka (0.05-0.8 birds/ha, Marchant and Higgins 1993; 0.008-0.12 birds/ha, Beauchamp 1997). The measured productivity of the Weka at Rakauroa was very low, with an average of 12 eggs being required to produce one independent offspring.

What management should be applied to bring the realized productivity closer to the potential value at East Cape? Our results indicate a reduction in predation risk may benefit Weka. Almost half the dead Weka we recovered (and two of three radio-carrying birds) had been killed by predators, probably ferrets. We could not ascertain causes of egg and chick loss, but obtained circumstantial evidence from a predator removal experiment that predation was a causal factor (Bramley 1996). Furthermore, Buff Weka Gallirallus australis hectori are harvested for human consumption, apparently without threat to the population on Chatham Island (Beauchamp et al. 1999), where the Pacific rat, Rattus exulans, ferrets, stoats and weasels, Mustela nivalis, are absent (King 1990).

If, as appears likely, a male-biased sex ratio is a feature of the population we studied, we predict an increase in the number of females under a regime of predator control. Male biases have been reported before in Weka populations (Carroll 1963b, Coleman et al. 1983, Brothers and Skira 1984) and in other rail species (Lord Howe Island Woodhen Tricholimnas sylvestris, Miller and Mulette 1985; Tasmanian Native Hen Tribonyx mortierii, Goldizen et al. 1993). Because males as well as females tend nests, workers have been reluctant to ascribe the smaller proportion of females to predation whilst incubating. However, other ground-nesting New Zealand birds exhibit male bias (e.g. Kakapo Strigops habroptilus, Heather and Robertson 1996) or lower female survival rates (Blue Duck Hymenolaimus malacorhynchos, Williams 1991), or have responded positively to a reduction in predation risk (Brown Kiwi Apteryx mantelli, Robertson et al. 1999). We further predict smaller average male Weka home ranges will be measured in response to predator control if a shortage of unpaired females causes males to use larger areas. 
Crypticity is a feature of rails (Johnson and Dinsmore 1986, Flores and Eddleman 1995). We found Weka made more use of cover ("bush" and "pines") in their home ranges than would be expected from a model of random behaviour. This cryptic behaviour and their disruptive colouration are consistent with an evolutionary history of predation on Weka by visually hunting predators including one that is now extinct (New Zealand Hawk Circus eylesi, Holdaway 1989). There are two unfortunate consequences for East Cape Weka: first, vegetation of the sort they prefer is being cleared on farms and second, cats and ferrets are common in that sort of vegetation (King 1990, Langham 1992). In fact, a subsidized programme of scrub clearance from 1979 to 1982 (McIntosh 1981) and the failure of fur farming initiatives using ferrets in the district (G. Scott pers. comm.) may together have contributed to the population reduction that followed the droughts and cyclone at East Cape (Beauchamp 1997). Imaginative incentives to retain uneconomic woodpiles, verges, and weedy areas in farmland are required at East Cape. If accompanied by control of predators, our data suggest this will lead to an increase in adult survival.

Our recommendation to control predators is also suited to a recovery strategy based around establishing new mainland Weka populations. We previously described how predation led to the failure of a release programme (Bramley and Veltman 1998) and note that a predator-proof fence will be used to protect Weka to be released at Karori Wildlife Sanctuary, a 210 ha reserve near Wellington, New Zealand (Karori Wildlife Sanctuary Trust 1999, unpubl.).

Finally, we can report on positive progress on minimizing road kills of Weka. Transit New Zealand, the state roading authority, in association with the local Department of Conservation office, has developed road signs warning motorists of Weka in the area.

\section{Acknowledgements}

This work was funded by grants from the New Zealand Lottery Science Board and World Wide Fund for Nature (NZ) to C.J.V. Other funding was made available by the Massey University Graduate Research Fund and the Department of Ecology. The East Coast conservancy of the Department of Conservation, Gisborne and Waikato branches of the Royal Forest and Bird Protection Society, Juken Nissho Ltd, Hikurangi Forest Farms Ltd, Footrot Flats Charitable Trust, The Clark Charitable Trust and the J.S. Watson Trust all contributed generously to this project. The authors wish to thank Andy Bassett and many volunteers for their field assistance and Catherine Beard who drew Figure 1. Drs A. Goldizen, W.R. Eddelman, R.A. Fordham and an anonymous referee commented constructively on an earlier draft of this manuscript.

\section{References}

Aebischer, N. J. and Robertson, P. A. (1992) Practical aspects of compositional analysis as applied to pheasant habitat utilization. Pp. 285-293 in I. G. Priede and S. M. Swift, eds. Wildlife telemetry: remote monitoring and tracking of animals. Chichester, U.K.: Ellis Horwood.

Aebischer, N. J., Robertson, P. A. and Kenward, R. E. (1993) Compositional analysis of habitat use from animal radio-tracking data. Ecology 74: 1313-1325. 
Beauchamp, A. J. (1997) The decline of the North Island Weka (Gallirallus australis greyi) in the East Cape and Opotiki regions, North Island, New Zealand. Notornis 44: 27-35.

Beauchamp, A. J. (1998) The ageing of Weka (Gallirallus australis) using measurements, soft parts, plumage and wing spurs. Notornis 45: 167-176.

Beauchamp, A. J., Van Berkum, B. and Closs, M. (1998) The decline of North Island Weka (Gallirallus australis greyi) at Parekura Bay, Bay of Islands. Notornis 45: 31-43.

Beauchamp, A. J., Butler, D. J. and King, D. (1999) Weka (Gallirallus australis) recovery plan: 1999-2009. Wellington, New Zealand: Department of Conservation.

Bramley, G. N. (1994) The autecology and conservation of the North Island Weka (Gallirallus australis greyi). Unpublished MSc thesis, Massey University, Palmerston North, New Zealand.

Bramley, G. N. (1996) A small predator removal experiment to protect North Island weka (Gallirallus australis greyi) and the case for single-subject approaches in determining agents of decline. N.Z. J. Ecol. 20: 37-43.

Bramley, G. N. and Veltman, C. J. (1998) Failure of translocated, captive-bred North Island Weka Gallirallus australis greyi to establish a new population. Bird Conserv. Internatn. 8: 195-204.

Bramley, G. N. and Veltman, C. J. (in press) Call survey method for monitoring endangered North Island Weka (Gallirallus australis greyi). Notornis.

Brook, B. W., Lim, L., Harden, R., and Frankham, R. (1997) Does population viability analysis software predict the behaviour of real populations? A retrospective study on the Lord Howe Island Woodhen Tricholimnas sylvestris (Sclater). Biol. Conserv. 82: 119128.

Brothers, N. P. and Skira, I. J. (1984) The Weka on Macquarie Island. Notornis 31: 145-154.

Carroll, A. L. K. (1963a) Food habits of the North Island Weka. Notornis 10: 289-300.

Carroll, A. L. K. (1963b) Sexing of Wekas. Notornis 10: 302-303.

Carroll, A. L. K. (1963C) Breeding cycle of the North Island Weka. Notornis 10: 300-302.

Coleman, J. D., Warburton, B., and Green, W. Q. (1983) Some population statistics and movements of the Western Weka. Notornis 30:93-107.

Flores, R. E. and Eddleman, W. R. (1995) California Black Rail use of habitat in Southwestern Arizona. J. Wildl. Manage. 59: 357-363.

Goldizen, A. W., Goldizen, A. R. and Devlin, T. (1993) Unstable social structure associated with a population crash in the Tasmanian Native Hen (Tribonyx mortierii). Anim. Behav. 46: 1013-1016.

Graeme, A. (1997) Weka find another home. Forest and Bird 285: 12.

Harrison, S. (1991) Local extinction in a metapopulation context: an empirical evaluation. Biol. J. Linn. Soc. 42: 73-88.

Heather, B. D. and Robertson, H. A. (1996) The field guide to the birds of New Zealand. Auckland, New Zealand: Viking Publishers.

Holdaway, R. N. (1989) New Zealand's pre-human avifauna and its vulnerability. N.Z. J. Ecol. 12: 11-25.

Hough, N. (1982) Determining range area from location data. Biotelem. Patient Monit. 9: 10-17.

Innes, J. G. and Hay, J. R. (1991) The interactions of New Zealand forest birds with introduced fauna. Acta XX Congr. Internatn. Orn.: 2523-2533.

IUCN (1994) IUCN red list categories. Gland, Switzerland: IUCN.

Johnson, R. R. and Dinsmore, J. J. (1986) The use of tape-recorded calls to count Virginia Rails and Soras. Wilson Bull. 98: 303-306.

Karori Wildlife Sanctuary Trust (1999) Karori Wildlife Sanctuary: description of proposal and assessment of environmental effects for possum, lagomorph, rodent, cat, mustelid, hedgehog and ungulate eradication in the Karori Wildlife Sanctuary Operational Area. 
Unpublished. Karori Wildlife Sanctuary Trust, 31 Waiapu Road, Wellington, New Zealand.

King, C. M. (1990) The handbook of New Zealand mammals. Auckland, New Zealand: Oxford University Press.

Langham, N. P. E. (1992) Feral cats (Felis catus L.) on New Zealand farmland, II. Seasonal activity. Wildl. Res. 19: 707-720.

Manly, B. F. J., McDonald, L. L. and Thomas, D. L. (1993) Resource selection by animals: statistical design and analysis for field studies. London: Chapman and Hall.

Marchant, S. and Higgins, P. J. (1993) Handbook of Australian, New Zealand and Antarctic Birds, 2. Raptors-Lapwings. Family Rallidae, pp. 486-488. Genus Gallirallus, pp. 506-520. Melbourne, Australia: Oxford University Press.

McIntosh, I. S. (1981) An analysis of the land development encouragement loan scheme. Wellington, New Zealand: Economics Division, Ministry of Agriculture and Fisheries.

McLennan, J. A., Potter, M. A., Robertson, H. A., Wake, G. C., Colbourne, R., Dew, L., Joyce, L., McCann, A. J., Miles, J., Miller, P. J. and Reid, J . (1996) Role of predation in the decline of kiwi Apteryx spp., in New Zealand. N.Z. J. Ecol. 20: 27-35.

Miller, B. and Mulette, K. J. (1985) Rehabilitation of an endangered Australian bird: the Lord Howe Island woodhen Tricholimnas sylvestris (Sclater). Biol. Conserv. 34: 55-95.

Robertson, H. A., Colbourne, R. M., Graham, P. J., Miller, P. J. and Pierce, R. J. (1999) Survival of brown kiwi (Apteryx mantelli) exposed to brodifacoum poison in Northland, New Zealand. N.Z. J. Ecol. 23: 225-231.

Saunders, A. (1990) Mapara: island management "mainland" style. Pp. 147-149 in D.R. Towns, C.H. Daugherty and I.A.E. Atkinson, eds. Ecological restoration of New Zealand islands. Wellington, New Zealand: Department of Conservation (Conserv. Sci. Publ. 2).

St Clair, C. C. and St Clair, R. C. (1992) Weka predation on eggs and chicks of Fiordland Crested Penguin. Notornis 39: 60-63.

Williams, M. (1991) Social and demographic characteristics of the blue duck Hymenolaimus malacorhynchos. Wildfowl 42: 65-86.

GARY N. BRAMLEY ${ }^{1}$ and CLARE J. VELTMAN ${ }^{2}$

Department of Ecology, Massey University, Private Bag 11-222, Palmerston North, New Zealand.

${ }^{1}$ Now at P.O. Box 180, Kaeo, Northland 0471, New Zealand.

${ }^{2}$ Now at Science and Research Unit, Department of Conservation, P.O. Box 10420, Wellington, New Zealand. 
